\title{
Gambaran Klinis dan Laboratoris Diabetes Melitus Tipe-1 pada Anak
}

\section{Clinical and Laboratories Features in Children with Type-1 Diabetes Mellitus}

\author{
Haryudi Aji C \\ Laboratorium IImu Kesehatan Anak Rumah Sakit Umum Dr. Saiful Anwar Malang
}

\begin{abstract}
ABSTRAK
Diabetes mellitus tipe 1 disebabkan oleh kerusakan sel $\beta$ pankreas sehingga produksi insulin tidak memadai. Gambaran klinis dan laboratorium telah banyak dipelajari. Penelitian ditujukan untuk mereview gambaran Klinis pada pasien yang didiagnosis diabetes melitus tipe 1 di laboratorium Ilmu Kesehatan Anak Rumah Sakit Umum Dr. Saiful Anwar antara tahun 2005 dan 2009. Penelitian deskriptif pada 27 pasien Diabetes Mellitus tipe 1, usia 1-14 tahun, tingkat kejadian diabetes mellitus tipe 1 di klinik rawat jalan selama periode 2005-2009 adalah 0,0034\%. Ada tiga puluh pasien diabetes mellitus tipe 1 dengan durasi penyakit lebih dari 2 tahun, dengan rasio laki-laki dan wanita adalah 1:1,7. Sebagian besar pasien tidak memiliki riwayat keluarga diabetes dan memiliki malnutrisi sedang. Frekuensi rata-rata pemantauan glukosa darah di rumah kurang dari ideal. 23 dari 27 pasien gambaran metabolik sepenuhnya terkendali. Pasien masih memiliki poliuria, polidipsia, dan polifagia. Semua pasien diabetes mellitus tipe 1 memiliki poliuria, polidipsia, polifagia dan penurunan berat badan. Mayoritas usia pasien 5-10 tahun dengan jenis kelamin perempuan. Sebagian besar pasien tidak memiliki riwayat Diabetes mellitus, dan pasien dirawat di rumah sakit dengan ketoasidosis diabetik, malnutrisi sedang, dan kadar gula darah lebih dari $300 \mathrm{mg} / \mathrm{dl}$.
\end{abstract}

Kata Kunci: Anak, DM tipe 1, gambaran klinis

\section{ABSTRACT}

The most common type 1 diabetes mellitus caused by destruction of $B$ cells pancreatic that leading to inadequate insulin production. Clinical and laboratory features of type 1 diabetes mellitus have been widely studied. We reviewed the clinical feature of patients diagnosed with Type 1 Diabetes Mellitus at the Pediatric Department of Saiful Anwar Hospital between 2005 and 2009. A descriptive study carried out based on clinical Type 1 Diabetes Mellitus of 27 patients, 1-14 years of age. The incidence rate of Type 1 Diabetes Mellitus in our outpatient clinic during the period from 2005 to 2009 was 0,0034\%. There were 30 cases of Type 1 Diabetes Mellitus patients with duration of illness more than 2 years, which male to female ratio of 1: 1.7. Most of these patients had no diabetic family history and had moderate malnourished nutritional status. The average frequency of blood glucose home monitoring was less than ideal. Twenty-three out of the 27 patients were fully controlled metabolically. Subjectively, these patients still have polyuria, polydipsia, and polyphagia. All of the patients with type-1 diabetes mellitus have symptoms of polyuria, polydipsia, polyphagia and weight loss. The majority of age was 5-10 years and female. Most patients had no history of Diabetes mellitus. Most patients were hospitalized due to diabetes ketoacidosis, moderate malnourished, and blood glucose level more than $300 \mathrm{mg} / \mathrm{dl}$.

Keywords: Clinical finding, children, type 1 Diabetes Mellitus

Jurnal Kedokteran Brawijaya, Vol. 26, No. 4, Agustus 2011: Korespondensi: Haryudi Aji C. Laboratorium Ilmu Kesehatan Anak Rumah Sakit Umum Dr. Saiful Anwar Malang, Jl. Veteran Malang Tel. (0341)366242 Email: ika fkub@yahoo.com 


\section{PENDAHULUAN}

Diabetes mellitus (DM) adalah kelainan yang bersifat kronis ditandai dengan gangguan metabolisme karbohidrat, protein dan lemak yang disebabkan defisiensi insulin baik absolut dan atau relatif (1). Defisiensi insulin absolut biasanya didapatkan pada pasien diabetes mellitus tipe-1. Hal ini disebabkan adanya kerusakan sel pankreas yang progresif sehingga insulin tidak dapat disintesis oleh kelenjar pankreas. Defisiensi insulin relatif ditemukan pada pasien DM tipe-2 dikarenakan kurang efektifnya pemakaian insulin di dalam tubuh (2). Sebagian besar penderita DM pada anak termasuk dalam DM tipe-1, yang terjadi akibat suatu proses auotimun yang merusak sel beta pankreas sehingga produksi insulin berkurang bahkan berhenti (3). Oleh karena itu penderita sangat tergantung pada insulin untuk kelangsungan hidupnya (4). Diabetes mellitus tipe-1 ini disebut juga DM Tergantung Insulin (DMTI). Penelitian di bagian Ilmu Kesehatan Anak Fakultas Kedokteran Universitas Indonesia RS Cipto Mangunkusuma (IKA FKUIRSCM) dari tahun 1973-1988 hanya didapatkan 28 pasien DM tipe-1 dengan usia terbanyak 6-10 tahun, anak perempuan mempunyai proporsi 3 kali lebih banyak dari laki-laki (5).

Sampai saat ini melalui penelusuran kepustakaan sedikit sekali tulisan di Indonesia mengenai karakteristik klinis dan laboratorium DM tipe-1. Hal ini mengakibatkan banyak tenaga medis yang tidak mengetahuinya sehingga sering sekali salah dalam mendiagnosis pasien DM tipe-1. Gambaran klinis yang khas pada DM tipe-1 berupa poliuria, polidipsi, polifagia dan adanya penurunan berat badan yang progresif sering terlupakan. Dengan demikian tindakan yang diberikan pada pasien tersebut tidak adekuat, sehingga pasien tersebut mengalami hiperglikemi kronis dan akhirnya jatuh dalam komplikasi yang berat seperti ketoasidosis diabetik (KAD), gangguan pertumbuhan dan komplikasi kronis lainnya berupa retinopati diabetika, nefropati diabetika, neuropati diabetika dan sebagainya (6-8). Selain itu masyarakat masih banyak yang kurang percaya bahwa DM bisa terjadi pada anak. Setelah anaknya dirawat dengan komplikasi akut seperti KAD orang tua baru menyadarinya. Gambaran klinis yang tidak khas perlu diperhatikan dan ditelusuri lebih lanjut untuk lebih menajamkan diagnosis seperti cepat lelah, kesemutan atau keram kaki. Gangguan kesadaran dan asidosis metabolik selalu bermanifestasi bila pasien datang dengan komplikasi KAD (4).

Pemeriksaan laboratorium darah perlu dikerjakan untuk menegakkan diagnosis pasti DM tipe-1. Pemeriksaan kadar gula darah, darah perifer lengkap, HbA1c, Cpeptida, dan bila pasien menderita KAD diperiksa juga analisis gas darah, ureum dan kreatinin, serta elektrolit darah $(6,9)$. Penelitian ini bertujuan untuk mengetahui gambaran klinis dan laboratorium DM tipe-1 pada anak saat pertama kali datang ke bagian IImu Kesehatan Anak RS Dr. Saiful Anwar. Dengan penelitian ini data yang tersajikan dapat dipakai oleh tenaga medis yang bekerja di klinik terdepan pelayanan kesehatan dalam mendiagnosis dan mengelola DM tipe-1 dengan baik.

\section{METODE}

Penelitian ini bersifat deskriptif retrospektif. Sampel diambil dari semua pasien DM tipe-1 yang berobat ke bagian laburatorium IImu Keshatan Anak Rumah Sakit Umum Dr. Saiful Anwar Malang antara tahun 2005-2009. Data dari catatan medis yang dikumpulkan meliputi sebaran umum dan jenis kelamin, riwayat klinis dan gejala klinis pasien diabetes mellitus tipe 1 . Analisis dilakukan dengan cara deskriptif.

\section{HASIL}

Seluruh sampel penelitian antara tahun 2005-2009 berjumlah 27 catatan medis pasien DM tipe-1 dengan 10 anak laki-laki dan 17 anak perempuan. Saat diagnosis DM tipe-1 (saat datang ke bagian IKA-RSSA) terbanyak pada usia 5-10 tahun pada 16 kasus (60\%) (Tabel 1).

Tabel 1. Sebaran umur dan jenis kelamin pasien saat diagnosis DM tipe-1

\begin{tabular}{ll}
\hline Usia (tahun) & Jumlah \\
\hline$<5$ & $4(15 \%)$ \\
$5-10$ & $16(59 \%)$ \\
$10-15$ & $5(19 \%)$ \\
$>15$ & $2(7 \%)$ \\
Jenis kelamin & \\
Laki-laki & $10(37 \%)$ \\
perempuan & $17(62 \%)$ \\
\hline
\end{tabular}

Dari 27 kasus DM tipe-1, hanya 34\% mempunyai riwayat keturunan keluarga DM, dan 66\% tidak mempunyai riwayat keturunan keluarga DM. Saat datang ke Bagian IKA-RSSA 78\% dengan KAD, 15\% pasca KAD (pasien menderita KAD bukan di RSSA), dan 7\% tidak menderita KAD. Tujuh puluh satu persen menderita gizi kurang dan $29 \%$ dengan gizi baik

Tabel 2. Riwayat klinis pasien DM tipe-1

\begin{tabular}{ll}
\hline \multicolumn{1}{c}{ Riwayat klinis } & Total \\
\hline Riwayat DM pada keluarga & \\
Riwayat keluarga (+) & $9(33 \%)$ \\
Riwayat keluarga (-) & $18(67 \%)$ \\
Keadaan pasien saat datang ke RSSA & \\
KAD di RSSA & $21(78 \%)$ \\
Paska KAD diluar RSSA & $4(15 \%)$ \\
Tidak KAD & $2(7 \%)$ \\
Status gizi pasien & \\
Gizi baik & $8(3 \%)$ \\
Gizi kurang & $19(70 \%)$ \\
Gizi buruk & $0(0 \%)$ \\
\hline
\end{tabular}

Sebagian besar pasien DM tipe-1 datang dengan keluhan poliuria, polidipsi, polifagia dan adanya penurunan berat badan progresif. Gangguan kesadaran dan asidosis metabolik, nyeri perut, muntah menyertai pasien dengan KAD. Hanya sebagian kecil kasus disertai dengan cepat lelah atau lemah (Tabel 3). 
Tabel 3. Gejala klinis pasien DM tipe-1

\begin{tabular}{ll}
\hline Gejala klinis & Jumlah \\
\hline Muntah & $7(26 \%)$ \\
Nyeri perut & $8(30 \%)$ \\
Penurunan kesadaran & $8(30 \%)$ \\
Kejang & $1(4 \%)$ \\
Diare & $1(4 \%)$ \\
Penurunan berat badan & $4(15 \%)$ \\
Poliuria & $10(37 \%)$ \\
Polidipsia & $8(30 \%)$ \\
Polifagia & $7(26 \%)$ \\
Demam & $4(15 \%)$
\end{tabular}

Kadar gula darah pasien DM tipe-1 saat datang pertama kali ke Bagian IKA-RSSA terbanyak antara 300-500mg/dl ( $52 \%$ kasus), lebih dari 500 mg/dl (37\% kasus), antara 200$300 \mathrm{mg} / \mathrm{dl}$ sebanyak $11 \%$ kasus. Kontrol metabolik yang baik hanya pada 4 pasien dan sebagian besar pasien (88\%) dengan kontrol metabolik yang kurang baik (Tabel 4 ).

Tabel 4. Kadar gula darah pasien DM tipe-1

\begin{tabular}{ll}
\hline Kadar gula darah $(\mathbf{m g} / \mathbf{d l})$ & Jumlah \\
\hline $200-300$ & $3(11 \%)$ \\
$300-500$ & $14(52 \%)$ \\
$>500$ & $10(37 \%)$ \\
Kontrol metabolik & \\
Terkontrol & $4(12 \%)$ \\
Terkontrol pertama kali & $1(38 \%)$ \\
Tidak terkontrol 6-8 minggu & $10(38 \%)$ \\
Tidak terkontrol 8-12 minggu & $6(23 \%)$ \\
Tidak terkontrol & $5(19 \%)$ \\
\hline
\end{tabular}

\section{DISKUSI}

Penelitian ini menggunakan desain deskriptif retrospektif untuk mengetahui gambaran klinis dan laboratorium DM tipe-1 pada anak saat datang pertama kali ke laboratorium Ilmu Kesehatan Anak Rumah Sakit Umum Dr. Saiful Anwar Malang.

\section{Riwayat DM Keluarga, Umur, dan Jenis Kelamin}

Dalam kurun waktu antara tahun 2005-2009 terdapat 27 catatan medis pasien DM tipe-1 dengan 10 anak laki-laki (37\%) dan 17 anak perempuan (63\%). Usia terbanyak adalah 5-10 tahun. Hal ini kemungkinan pada rentang usia tersebut merupakan masa yang sangat rentan terkena infeksi (10-12). Kondisi infeksi akan meningkatkan islet autoantibodi yang berkembang menjadi diabetes melitus tipe-1 (12-14). Menurut Tridgell et al onset DM tipe-1 dipengaruhi kadar antibodi, usia kurang 5 tahun banyak mengandung insulinoma-antigen 2 antibodies (IA-2A) dan pada usia lebih tua/diatas 10 tahun banyak terdapat GAD antibodi $(4,11)$. Terlihat disini bahwa proporsi anak perempuan hampir 2 kali lebih banyak dari anak laki-laki dan usia terbanyak terdapat antara 5-10 tahun. Hal ini

\section{DAFTAR PUSTAKA}

1. WHO Study Group on Prevention of Diabetes Mellitus. Prevention of Diabetes Mellitus. World sesuai dengan penelitian Assin et al bahwa anak perempuan lebih banyak menderita DM tipe 1 dibandingkan dengan anak laki-laki dengan usia terbanyak 6-10 tahun (5). Di Amerika Serikat angka kejadian DM tipe 1 terbanyak pada rentang usia 9-12 tahun dan anak perempuan dua kali lebih banyak dari anak laki-laki $(15,16)$.

Pada penelitian ini didapatkan riwayat DM keluarga pada $30 \%$ pasien. Faktor genetik dan lingkungan sangat berperan pada terjadinya DM tipe-1 (17). Dari kepustakaan, walaupun hampir $80 \%$ penderita DM tipe-1 baru tidak mempunyai riwayat keluarga dengan penyakit serupa, faktor genetik diakui berperan dalam patogenesis DM tipe-1. Faktor genetik dikaitkan dengan pola HLA tertentu, tetapi sistem HLA bukan merupakan satusatunya faktor, diperlukan suatu faktor yang berasal dari lingkungan seperti infeksi virus, toksin, untuk memicu gejala klinis DM tipe-1. Gen HLA yang berkaitan dengan kejadian DM lebih sering ditemukan pada penderita yang terdiagnosis DM saat dewasa (14,18-20).

\section{Gambaran Klinis}

Dari gambaran klinis terlihat bahwa poliuria, polidipsi, polifagia dan penurunan berat badan terjadi pada sebagian besar pasien DM tipe-1. Hal ini sesuai dengan penelitian lain bahwa ke empat gejala klinis ini hampir terjadi pada seluruh pasien DM tipe-1 (6-15). Dibanding dewasa, DM pada anak mempunyai gambaran klinis yang lebih akut, lebih berat dan tergantung insulin.

Pada keadaan KAD seluruh kasus yaitu 27 (100\%) kasus mempunyai gejala sesak nafas dan penurunan kesadaran serta nyeri perut. Hal ini sesuai dengan penelitian lain bahwa pada keadaan KAD selalu bermanisfestasi adanya penurunan kesadaran dan asidosis metabolik dan nyeri perut. Penderita biasanya datang dengan ketoasidosis karena keterlambatan diagnosis. Gejala yang sering muncul pada ketoasidosis adalah nyeri perut hebat, penurunan kesadaran, muntah, hal ini sering dikaburkan dengan penyakit lain seperti apendisitis, ensefalitis ataupun gastroenteritis.

\section{Gambaran Laboratoris}

Hiperglikemia dijumpai pada seluruh pasien DM tipe-1. Kadar glukosa darah terbanyak dijumpai antara 300-500 $\mathrm{mg} / \mathrm{dl}$ pada 14 kasus (52\%), lebih dari $500 \mathrm{mg} / \mathrm{dl}$ pada 10 (37\%) kasus dan antara $200-300$ mg/dl pada 5 (12\%) kasus. Diagnosis DM sudah dapat ditegakkan bila memenuhi salah satu kriteria, yaitu bila ditemukan gejala klinis poliuria, polidipsia, polifagia, berat badan menurun, dan kadar glukosa darah sewaktu lebih dari 200 mg/dl. Bila tanpa gejala, diagnosis ditegakkan bila kadar glukosa darah sewaktu harus lebih $200 \mathrm{mg} / \mathrm{dl}$ atau kadar gula darah puasa lebih tinggi dari normal atau dengan tes toleransi glukosa kadar glukosa darah puasa $>140 \mathrm{mg} / \mathrm{dl}(13,21-23)$. Hanya terdapat 4 pasien dengan kontrol metabolik yang baik, sedangkan 23 pasien lainnya dengan kontrol metabolik yang kurang baik. Studi ini menunjukkan bahwa DM tipe 1 pada anak lebih banyak pada perempuan, usia 510 tahun, dengan gambaran klinis akut.

Health Organization Technical Report Series, Geneva; 1994.

\section{Wijaya A. Pemeriksaan Laboratorium untuk Diagnosis}


dan Pengelolaan Diabetes Melitus. Prodia Diagnostic Educational Services. 1997; 1: 1-16.

3. Sosenko JM, Krischer JP, Palmer JP, et al. A Risk Score for Type 1 Diabetes Derived From AutoantibodyPositive Participants in the Diabetes Prevention TrialType 1. Diabetes Care. 2008; 31(3): 528-533.

4. Grunnet LG and Mandrup-Poulsen T. Cytokines and Type 1 Diabetes: A Numbers Game. Diabetes. 2011; 60(3): 697-699.

5. Sutan-Assin M, Rukman Y and Batubara JR. Childhood Onset of Diabetes Mellitus Report on Hospital Cases. Paediatrica Indonesiana. 1990; 30(7): 209-212.

6. Arslanian S, Becker D, and Drash A. Diabetes Mellitus in the Child and Adolescents. In: Kappy MS (Ed). The Diagnosis and Tretment of Endocrine Disorders in Childhood and Adolescence 4th edition. Illinois: Charles C.Thomas; 1994; p. 961-1024.

7. Hershman JM. Endocrine Pathophysiology a Patient Oriented Approach. Philadelphia: Lea and Febiger; 1977; p. 207-243.

8. David L. Wodrich, Khalid H and Kelly B. Parent. Type 1 Diabetes Mellitus and School: A Review. Pediatric Diabetes. 2011; 12(1): 63-70.

9. Danne T, Lange $\mathrm{K}$, and Kardonouri O. New Developments in The Treatment of Type 1 Diabetes in Children. Archives of Disease in Chilhood. 2007; 92(11): 1015-1019.

10. Ivakine EA, Mortin-Toth SM, Gulban OM, et al. The Idd4 Locus Displays Sex-Specific Epistatic Effects on Type 1 Diabetes Susceptibility in Nonobese Diabetic Mice. Diabetes. 2006; 55(12): 3611-3619.

11. Tridgell DM, Spiekerman C, Wang RS and Greenbaum CJ. Interaction of Onset and Duration of Diabetes on the Percent of GAD Antibody and Insulinoma-Antigen 2 Antibodies-Positive Subjects in the Type 1 Diabetes Genetic Consortium Database. Diabetes Care. 2011; 34(4): 988-993.

12. Snell-Bergeon JK, West NA, Mayer-Davis EJ, et al. Inflammatory Markers are Increased in Youth with Type 1 Diabetes: The SEARCH Case-Control Study. The Journal of Clinical Endocrinology and Metabolism.
2010; 95(6): 2868-2876.

13. Hassan K and Heptulla RA, and Heptulla. Glycemic Control in Pediatric Type 1 Diabetes: Role of Caregiver Literacy. Pediatrics. 2010; 125(5): e1104-e1108.

14. Anaya JM, Gomez LM, and Castiblanco J. Is there a Common Genetic Basis for Autoimmune Diseases? Clinical and Developmental Immunology. 2006; 13(24): 185-195.

15. Travis LB, Brouhard BH, and Schreneir BJ. Diabetes Mellitus in Children and Adolescents. Philadelphia: WB saunders Company; 1987; p. 18-72.

16. Kalyva E, Malakonaki E, Eiser C, and Mamoulakis D. Health-Related Quality of Life (HRQoL) of Children with Type 1 Diabetes Mellitus (T1DM): Self and Parental Perceptions. Pediatric Diabetes. 2011; 12(1): 34-40.

17. Smaldone A and Ritholz MD. Perceptions of Parenting Children With Type 1 Diabetes Diagnosed in Early Childhood. Journal of Pediatric Health Care. 2011; 25(2): 87-95.

18. Jose RL. Konsensus Nasional Pengelolaan Diabetes Mellitus Tipe-1 di Indonesia. Jakarta: Ikatan Dokter Anak Indonesia; 2000.

19. Silink M. APEG Handbook on Childhood and Adolescent Diabetes The Management of InsulinDependent (Type 1) Diabetes Mellitus (IDDM ). Paramatta: Australasian Paediatric Endocrine Group; 1996.

20. Cardwell CR, Stene LC, Joner G, et al. Birth Order and Childhood Type 1 Diabetes Risk: A Pooled Analysis of 31 Observational Studies. International Journal of Epidemiology. 2011: 40(2):363-374.

21. Sperling MA. Diabetes Mellitus. In: Sperling MA (Ed). Pediatric Endocrinology 2nd Edition. Philadelphia: Saunders; 2006: p. 351.

22. Hanas R, Donaghue KC, Klingensmith G and Swift PG. ISPAD Clinical Practice Consensus Guidelines 2009 Compendium. Pediatric Diabetes. 2009; 10(12): 1-2.

23. Hatherly K, Smith L, Overland J, et al. Glycemic Control and Type 1 Diabetes: The Differential Impact of Model of Care and Income. Pediatric Diabetes. 2011;12(2): 115-119. 